\title{
IMPROVING ENVIRONMENTAL HEALTH THROUGH REDUCE REUSE RECYCLE (THE 3RS) AND TRASH CANS WITH ATTRACTIVE PICTURES AT HIGH SCHOOL IN PERCUT SEI TUAN SUB-DISTRICT
}

\author{
Evi Naria ${ }^{1)}$, Ernawati Nasution ${ }^{2)}$, Devi N Santi ${ }^{3)}$ \\ 1) Fakultas Kesehatan Masyarakat, Universitas Sumatera Utara \\ Email: evi3@usu.ac.id \\ 2) Fakultas Kesehatan Masyarakat, Universitas Sumatera Utara \\ Email: ernawati@usu.ac.id \\ 3) Fakultas Kesehatan Masyarakat, Universitas Sumatera Utara \\ Email: devi@usu.ac.id
}

\begin{abstract}
Waste management should be carried out by implementing the concept of the 3 Rs. Waste is generated in various places including in schools. Students frequently do not collect the waste into a trash can and often leave the waste in the schoolyard, desk drawers. Even though the slogan "keep the school clean" is instructed to the students, but they still often litter the school environment. This activity aims to improve students' litter education in waste management by implementing the 3 Rs and providing trash cans with attractive pictures to attract students to collect the waste into the trash cans. The method was participatory method and training to manage waste based on the concept of the 3Rs. The result shows that students were able to manage waste by applying the concept of the 3Rs. Students understood the concepts of the 3Rs, and created some products such as phone stand, hand soap dispenser, and reusable grocery bags. Trash cans with attractive pictures were provided in several areas around the school such as teachers' room, canteen, and classroom. Students actively participated in waste management by applying the 3Rs. This activity beneficially reduces environmental pollution and simultaneously improves personal autonomy in environmental sustainability.
\end{abstract}

Keywords: The 3Rs, Attractive pictures, Waste management

\section{INTRODUCTION}

Solid waste is largely found in our environment since people do various daily activities that generate waste. Waste is a cultural problem since it affects various aspects of life. Therefore, the waste needs to be properly managed to minimize the negative impacts of waste on the environment. Waste management is expected to be able to improve environmental cleanliness and environmental aesthetics, prevent pollution, and reduce disease transmission pathways. The waste materials are very diverse, but in general, the waste contains $75 \%$ organic waste and $25 \%$ inorganic waste.
When the solid waste is not managed with a proper waste management method, the waste can adversely impact human health and the environment, especially in metropolitan cities such as Jakarta, Semarang, Surabaya, Bandung, Palembang, and Medan. A survey found that the volume of solid waste generated in Jakarta, Bogor, Bandung, and Surabaya in 1987 was $0.5 \mathrm{~kg} /$ capita/day (Sudrajat, 2006). It is predicted that metropolitan cities such as Jakarta, whose population reaches 10 million, produces solid waste approximately 5,000 tons/day. The potential waste production in Bandung was 1.300 tons/day and 1.500 tons/day in Surabaya. 
The excessive solid waste causes short and long-term effects, especially on human health. Short-term effects occur when human directly contact with infected waste, such as toxic waste and waste with pathogenic microorganisms, which can cause various health problems. Long-term effects occur when waste piles become the habitat of various disease vectors which will cause to the water, air, and soil pollution. Therefore solid waste must be properly managed to minimize the risks to human health. Proper waste management does not only positively impact on human health, but also on environmental aesthetics.

The 3Rs is one of the most effective methods that should be implemented in waste management. According to Law Number 18 of 2008 concerning waste management, reduce is an attempt to reduce waste production which includes saving and selecting materials by considering their characteristics such as minimizing the use of the hazardous material. Reuse is an attempt to reuse goods without any change and process. Recycle is an attempt to use goods for other purposes by changing or processing the waste become new goods. According to Aryenti (2011), improper waste management method can cause various risks to human health and the environment.

The 3Rs waste management offers environmental, social, and economic benefits (Suwerda, 2012). A proper method in waste management can reduce the waste piles around the settlements and eradicate resting sites and breeding sites of vectors. Thus, the environment becomes cleaner and more comfortable for the human. Moreover, recycling the solid waste will produce products which can be sold to strengthen household economically.

Apinhapath (2014) states a sustainable waste management is required to solve waste problems and to achieve environmental sustainability. It is effective to reduce waste management costs of each process including collection, transportation, processing, and recycling or final disposal.

Waste is usually produced where people gather to do certain activities such as schools. Students carry out various activities that can produce solid waste. Sadly, schools as a second home for students generally still do not have good waste management. School should be clean so that students are comfortable to learn. But, several schools still have scattered waste around the school environment. Taufik (2016) conducted a study on school waste management and found that $39.87 \%$ of students sometimes put the waste in any area in the school environment and $19.26 \%$ of students never put waste into a trash can. School activities were finished and solid waste was scattered around the school environment. The materials of school waste were very diverse such as paper, plastic food packaging, and water bottle waste. Even though the slogan "keep the school clean" was instructed to students, but they still left waste everywhere, including in the desk drawers. The researcher suggested the other researchers provide trash cans in that school and hold an extracurricular program to teach students about waste management, at least about personal waste management since another study found that personal waste can reach $0.8 \mathrm{~kg} / \mathrm{day}$.

Karlina (2017) studied eco-literacy (ecological awareness) of students in waste management activities. The study found that after following two cycles of outdoorbased learning study, students' eco-literacy increased in several aspects: knowledge (20\%), application $49.6 \%$, and attitude (19.4\%). According to Widyaningrum (2015), the participation level of high school students in managing school waste was active category with a mean score of 166.5. Meanwhile, students' knowledge of waste management was good enough with a score of 15.2. According to Boiyo (2015), students generally have a negative attitude toward student participation in 
Evi. et.al. Improving Environmental Health Through Reduce Reuse Recycle (The 3rs) and Trash Cans with Attractive Pictures at High School in Percut Sei Tuan Sub-District

environmental cleanliness in school. Students often assume that school environmental cleanliness is the responsibility of school janitors.

According to Musfirah (2017), school waste management needs to be taken seriously. Students generally still do not manage waste optimally. In Musrifah's study, the students were taught theoretically and practically about waste management. After the treatments, it was found that the experimental group and control group were different with a $\mathrm{p}$-value of 0.041 .

This study is a public service as an intervention in environmental health by implementing the $3 \mathrm{Rs}$ and providing trash cans with attractive pictures, especially interesting images, at two high schools in Percut Sei Tuan Sub-district, Deli Serdang Regency. It is regrettable that schools as the second place for students still do not implement a proper waste management. Solid waste is still scattered around the school environment. Therefore, this activity will help schools to create a better waste management. Trash cans with attractive pictures of interesting images provided in schools are expected to attract students to actively participate in waste management.

\section{METHOD}

The target of this study was people who are economically unproductive. Therefore, students were choosen to be the participants. The activity involved 50 students from two high schools in Deli Serdang Regency: 25 students of Madrasah Tsanawiyah Aisyiyah and 25 students of SMK Mandiri. Students were trained to implement the $3 \mathrm{Rs}$ to ensure that students will be able to practically reduce, reuse, and recycle waste in school and other environments. Through this training, students were expected to have skills in recycling solid waste to be beneficial goods. To support the training, trash cans with attractive pictures were provided in several strategic areas in the schools. Trash cans with attractive pictures were expected to attract students to actively participate in waste management.

\section{RESULT}

\subsection{Waste management training with the concept of the $3 R s$}

The information about the concept of reuse and its example were provided for students. Then, students were asked to give other examples of goods to reuse. Students reported some reuse activities that they did such as storing plastic bags, using cloth handkerchief than the tissue, and using a rechargeable battery.

The definition of reduce, as an attempt to minimize waste production, was explained to the students. Several examples were also provided to the student to ensure they really understand the concept of reduce such as using reusable water bottles, taking refill products, and bringing their own grocery bags. Students then reported the example of reduce activities that they did such as using reusable water bottles to schools. The survey showed that $68 \%$ of students brought reusable water bottles to school. It means that students did not buy bottled mineral water which can produce plastic bottle waste.

Students also got information about the concept of recycling as processing the waste to become beneficial and valuable goods. Students were trained to recycle various waste materials and create several kinds of products such as phone stand, hand soap dispenser, and grocery bags.

1. Phone stand

Phone stand was made from used a cardboard box. All students were able to create phone stands easily. Students were highly interested in this product since every student had a phone. Phone stand is needed to get a safe phone position. Students were satisfied with their product since they can use it. 
2. Hand soap dispenser

Hand soap dispenser was made from disposable bottles. All students of SMK Mandiri finished this product smoothly. Meanwhile, only $60 \%$ of Madrasah Tsanawiyah Aisyiyah who finished the product based on the indicators.

3. Grocery bag

The grocery bag was made from a used $\mathrm{t}$-shirt. All sizes of $\mathrm{t}$-shirt can be used to make grocery bags. The process of creating a grocery bag from a used tshirt is easy. It only consists of two simple processes: cutting and tying. About $90 \%$ of students were able to finish this product well. Besides for grocery bags, students can also use the bag to bring their books and water bottle to school. Some students reported that they used the bags to bring goods when they went swimming. Meanwhile, some students planned to make other bags and sell them to earn money.

\subsection{Creating waste management slogan}

In the activity, there was a session in which students were encouraged to creatively create several slogans about waste management. This session aimed to improve students' awareness of the importance of environmental cleanliness. The slogans become a persuasion to other students to participate in maintaining environmental health. There were four selected slogans which were printed on banners, as following:

1.Smart students keep the environment clean

2. Clean environment for clean hearth and soul

3. Take care of nature, nature will take care of you

4.Don't be a litterbug

\subsection{Providing trash cans with attractive pictures}

Trash cans with interesting images aimed to attract students to put waste into the trash can and built student habitual to not litter in the school environment. Trash cans with images were especially ordered from a factory. The trash cans were creatively designed by using interesting images and colors. Various images about the beauty of nature, such as flowers, were chosen to persuade students to love the nature. Several cartoon images were also used since the students like cartoons.

The trash cans were located in several strategic and accessible areas such as classrooms, canteen, and schoolyard. The areas were considered as strategic areas since the students often do activities and usually produce solid waste there. Trash cans were also located in some other areas, such as teacher' room. So that the teachers can be a role model for students in participating in school environmental health.

This activity helped the schools to inform the students about students' role in supporting the programs of school waste management. Thus, all students were expected to understand about waste management. The students can practice the 3Rs method, especially to recycle waste to become beneficial goods. Students can process the waste to be beneficial and valuable goods which they can use for their daily activities. Therefore, the awareness of waste utilization as an opportunity to earn own money grows in students' mind.

This activity also improved students' skills and understanding of waste management in their environment. Thus, the waste problems in the school can be properly solved by involving students to participate in waste management. Students' understanding of waste management will encourage them to practice waste 
management and to be responsible for their personal waste.

Schools are cleaner, beauty, and comfortable for students. Trash cans with attractive images are available in schools to encourage them to be responsible to put their waste into the trash cans. In addition, there are several banners which persuade students to participate in school waste management.

All students involved in the activity comprehensively understood the implementation of the concept of the 3Rs in the school environment. Furthermore, they will implement their knowledge of waste management in other environments besides schools, such as family and other environments. The practice of the recycle, creating grocery bags, phone stand, and hand soap dispenser, aimed to provide students the information about waste management by implementing the principle of the 3Rs (Reuse, reduce, and recycle). Students understood the concept of the 3Rs by the practice of reusing an unused t-shirts (reuse), using their own grocery bags (reduce), and creating new beneficial goods from the unused t-shirts (recycle).

Practically, this activity helps to reduce environmental pollution and improve students' autonomy in maintaining a clean and healthy environment. Banners, with the slogans which persuade students to do waste management, are an effective media since students will see the banners every day. Thus, students will be encouraged to always remember school waste management. Students can also practice their knowledge of waste management in other places besides the schools, such as at home. Waste management is an activity which should be done continually to stop the growth of waste piles. Waste, which is assumed as unuseful goods, can be recycled to become beneficial and invaluable goods.

\section{CONCLUSION}

The students were trained to manage solid waste by implementing the concept of Reuse, Reduce and Recycle (the 3Rs). Students were able to create some products from solid waste such as grocery bags from an unused t-shirt, hand soap containers, and phone stands. Trash cans, with attractive images, which were located in several strategic areas in the schools, can improve the participation of students and teachers to maintain school environment cleanliness. Moreover, the slogans can encourage students to have better perception toward waste management.

\section{RECOMMENDATION}

Students and teachers need to continually improve their participation in waste management by implementing the concept of the 3Rs. Trash cans with attractive pictures can be used to maintain a clean and healthy school environment by collecting the solid waste into the trash cans. Students involved in the activity are expected to retell their knowledge of waste management with the concept of the 3 Rs to their family, friends, and neighbors. It is also suggested to school to hold and support the events related to waste management, such as holding a competition for recycling unused goods.

\section{ACKNOWLEDGMENT}

We would like to thank the Rector of University of Sumatera Utara for funding this project through a Program Pengabdian Tahun 2018 scheme. In addition, our sincere thank also goes to the Community Service Institute of the University of Sumatera Utara for the facilities during the completion of this project.

\section{REFERENCES}

Aryenti, 2011. Peningkatan Peran Serta Masyarakat melalui Gerakan Menabung pada Bank Sampah di Kelurahan Babakan. 
Evi. et.al. Improving Environmental Health Through Reduce Reuse Recycle (The 3rs) and Trash Cans with Attractive Pictures at High School in Percut Sei Tuan Sub-District

Kiaracondong Bandung. Jurnal Pemukiman Vol 6 (1).

Taufik, Muhammad. et al. 2016. Upaya pengembangan model pengelolaan sampah di SMK Kawasan Surabaya Barat. Prosiding Seminar Nasional Biologi. ISBN 978-6020951-11-9

Pratama, Anggi Tias. 2014. Sistem Pengolahan Sampah Ramah Lingkungan di Sekolah Kota Medan. Jurnal Biology and Education Vol 3 No 2 Edisi Juli - Desember 2014

Sudrajat, 2002. Mengelola Sampah. Penebar Swadaya. Jakarta,

Karlina, Fanny ; I Nyoman Sudana ; Amirudin. 2017. Ecoliteracy siswa dalam kegiatan pengelolaan sampah melalui group investigation berbasis outdoor study. Jurnal Pendidikan Volume 2 Nomor 7 Bulan Juli Tahun 2017. Hal 991 -1002

Undang Undang RI No 18 Tahun 2008 Tentang Pengelolaan Sampah. www.sanitasi.net/undangundang-no-18-tahun2008-tentangpengelolaan-sampah.html
Suwerda, Bambang. 2012. Bank Sampah Buku I. Werda Press Yogyakarta.

Widyaningrum, Priyantini ; Lisdiana ; Eling Purwantoyo. 2015. Evaluasi partisipasi siswadalam mengelola sampah untuk mendukung program sekolah adiwiyata. Indonesian Journal of Conservation Volume 4 No $\quad 1 \quad$ Tahun 2015. https://journal.unnes.ac.id/nju/index.php/ijc/art icle/view/5161

Musfirah 2017. Peningkatan Sikap siswa dalam mengolah sampah di SMK 3 Muhammadiyah Yogyakarta. The $5^{\text {th }}$ URECOL Proceeding. Yogyakarta.

Boiyo, V. Koech.M., Manguriu,D. 2015. Environmental Attitudes and Ecological Behaviour Among students : A case Study of Kibera and Kasarani division in Nairobi, Kenya. International Journal of Interdisciplinary Research and Innoovation. ISSS 2348-1226 Vol 3, Issue 1. 50 -59

Apinhapath, C. 2014. Community Mapping and Theory of Planed Behaviour. Journal of Waste Management. 